Dorota Łobos-Kotowska

\title{
Sprawozdanie z XXV Europejskiego Kongresu i Kolokwium Prawa Rolnego Queens' College, Cambridge, 23-27 września 2009 r.
}

W dniach 23-27.09.2009 r. w Cambridge odbył się XXV Europejski Kongres Prawa Rolnego, połączony z Kolokwium, które stanowiło platformę wymiany doświadczeń dla teoretyków i praktyków zajmujących się prawem rolnym w krajach Unii Europejskiej. W Kongresie udział wzięli przedstawiciele nauki prawa rolnego, praktycy oraz członkowie krajowych stowarzyszeń prawa rolnego z państw członkowskich UE. W tegorocznym spotkaniu udział wzięli także przedstawiciele państw spoza Wspólnoty, w tym w szczególności Stanów Zjednoczonych Ameryki, Argentyny, Australii, Japonii i Turcji. Organizatorem Kongresu było Europejskie Stowarzyszenie Prawa Rolnego (CEDR) we współpracy z Stowarzyszeniem Prawa Rolnego Wielkiej Brytanii (ALA). Polskę reprezentowali: prof. dr hab. A. Lichorowicz (UJ) - wiceprzewodniczący CEDR, prof. dr hab. A. Jurcewicz (PAN) - delegat krajowy CEDR, prof. dr hab. Roman Budzinowski (UAM w Poznaniu), prof. dr hab. M. Korzycka-Iwanow (UW), prof. dr hab. T. Kurowska (UŚ), prof. dr hab. E. Tomkiewicz (PAN), dr P. Blajer (UJ), dr D. Kokoszka (UJ), dr D. Łobos-Kotowska (UŚ), dr M. Stańko (UŚ), mgr S. Balcerak (Uniwersytet w Poznaniu), mgr J. Zięba $(\mathrm{PAN})$.

Uroczystego otwarcia Kongresu, połączonego z wygłoszeniem inauguracyjnych wystąpień, dokonali: prof. dr Erkki Hollo - przewodniczący CEDR, Roderick Mackay - przewodniczący Stowarzyszenia Prawa Rolnego Wielkiej Brytanii, dr Marc Heyerick - sekretarz generalny CEDR oraz prof. dr Daniele Bianchi - Przedstawiciel Komisji Europejskiej. We wszystkich przemówieniach podkreślone zostały zmiany zachodzące we WPR oraz wpływ wspólnotowego prawa rolnego na krajowy porządek prawny. Obrady uczestników Kongresu prowadzone były w trzech komisjach tematycznych.

Prace pierwszej komisji obejmowały problematykę prawnych instrumentów stymulujących i hamujących dywersyfikację działalności rolników. Podstawowym problemem, który wyłonił się w trakcie dyskusji, był brak w regulacjach krajowych 
ustawowych definicji dywersyfikacji. Brak definicji skłonił uczestników do poszukiwania zakresu tego pojęcia nie tylko w ujęciu jurydycznym, ale także w ujęciu ekonomicznym, jako różnicowanie struktury produkcji rolniczej oraz różnicowanie działalności prowadzonej w gospodarstwie rolnym w kierunku prowadzenia działalności innej niż rolnicza. Interesująca dyskusja dotyczyła relacji dzierżawcy i właściciela gospodarstwa rolnego w odniesieniu do możliwości podejmowania przez dzierżawcę działań dywersyfikacyjnych. Wyraźnie wskazać można było dwie zasadnicze tendencje, polegające na bezwzględnym wymogu uzyskania zgody właściciela gospodarstwa na dywersyfikację lub możliwości swobodnego ukształtowania w umowie dzierżawy praw i obowiązków stron w tym zakresie. Ponadto uczestnicy $\mathrm{w}$ raportach narodowych podnosili brak prawnych zachęt do dywersyfikacji w zakresie finansowych instrumentów w ramach planów rozwoju obszarów wiejskich i systemów płatności bezpośrednich. Szczególnie system płatności bezpośrednich, w ocenie większości uczestników komisji, nie jest aktywnym instrumentem dywersyfikacji, a w przeważającej mierze ma charakter socjalny. Jego zasadniczym celem jest udzielanie wsparcia posiadaczom gruntów rolnych utrzymywanych zgodnie z normami. Sama możliwość wsparcia określonej produkcji rolnej i dostosowania wielkości stawki płatności do preferowanego przez dane państwo profilu produkcji nie wydaje się wystarczającym rozwiązaniem. Zachętą do dywersyfikacji w większości państw nie są również systemy podatkowe i ubezpieczeń społecznych. Autorzy polskiego raportu, prof. dr hab. T. Kurowska i dr M. Stańko podkreślili, że dywersyfikacja gospodarstw rolnych jest zgodna z celami polityki wielofunkcyjnego rozwoju obszarów wiejskich. Polski system prawny ma jednak w tym zakresie charakter dość statyczny, a w każdym razie w zbyt słabym stopniu stymulujący dywersyfikację gospodarstw rolnych. Postulować zatem należy potrzebę określenia funkcji i celów, jakim dywersyfikacja ma służyć, szerokie określenie sfer działalności pozarolniczej, które mogą być realizowane na obszarach wiejskich. Konieczne wydaje się także kompleksowe uregulowanie dzierżawy nieruchomości rolnych oraz reaktywacja sprawnej administracji rolnej, zdolnej do kontroli działalności rolniczej, która staje się działalnością w coraz większym stopniu wyspecjalizowaną. Nie bez znaczenia pozostają także instrumenty finansowe, które są oczywistym stymulatorem rozwoju aktywności pozarolniczej na obszarach wiejskich. Konkluzje przedstawione w polskim raporcie były zbieżne z projektem raportu końcowego pierwszej komisji.

Program naukowy realizowany w drugiej komisji dotyczył prawnych form organizacji gospodarstw rolnych, z rozróżnieniem na tradycyjne gospodarstwa rolne i przedsiębiorstwa rolne. Wśród krajów europejskich najbogatsze rozwiązania w tym zakresie zaprezentowane zostały w raportach francuskim i włoskim. Państwa te stworzyły bowiem całe spektrum prawnych form specyficznych dla organizacji gospodarstw rolnych. W polskim raporcie przygotowanym pod kierunkiem prof. dr 
hab. A. Lichorowicza przez dr P. Blajera i dr D. Kokoszkę przeprowadzono analizę prawnych form organizacji gospodarstw rolnych, ze wskazaniem ich zalet i wad konstrukcyjnych. Autorzy nie pominęli także form współdziałania rolników, takich jak: grupy producentów rolnych, spółdzielnie czy stowarzyszenia, które nie prowadzą do powstania gospodarstw rolnych, a służą raczej poprawie efektywności gospodarowania i dostosowaniu gospodarstw do wymogów rynku poprzez współdziałanie w wybranych obszarach (marketing, wspólna sprzedaż, wspólne korzystanie ze sprzętu). Zdaniem Autorów, żadna z przewidzianych w polskim prawie form organizacji prawnej nie jest dostosowana do specyficznych wymogów polskiego rolnictwa, które cechuje bardzo rozdrobniona struktura agrarna, niewielka powierzchnia użytków rolnych i niedostatek kapitału. Konieczne zatem stało się sformułowanie instytucji prawnej współdziałania rolników, przewidzianej głównie dla niewielkich gospodarstw rolnych. Organizację taką cechować powinno zminimalizowanie wymogów formalnych na etapie jej tworzenia i funkcjonowania oraz konieczność ograniczenia odpowiedzialności za zobowiązania uczestników. W podsumowaniu prac komisji dyskutanci byli zgodni, że należy poszukiwać modelowego rozwiązania w zakresie prawnej formy organizacji gospodarstwa rolnego, przy uwzględnieniu rozróżnienia na wspólnie prowadzone gospodarstwa rolne i formy prawne współdziałania producentów rolnych. Dyskutanci podkreślali, że nie bez znaczenia dla wyboru prawnej formy są rozwiązania w zakresie obciążeń publicznoprawnych.

Temat podjęty przez trzecią komisję był szczególnie istotny. Dotyczył bowiem kierunków rozwoju prawa rolnego z uwzględnieniem zasad WTO, ustawodawstwa WPR i ustawodawstwa krajowego. Prace prowadzone w trzeciej komisji miały zatem bardziej doktrynalny i naukowy charakter, przy uwzględnieniu praktycznych aspektów stosowania prawa rolnego. Problem dyskutowany był na trzech płaszczyznach: międzynarodowej, europejskiej i krajowej. W płaszczyźnie międzynarodowej uczestnicy dyskusji poszukiwali kompromisu pomiędzy zasadami WTO, założeniami WPR i krajową polityką w zakresie rolnictwa. Państwa członkowskie UE pozostają bowiem stronami umów dwustronnych i wielostronnych z państwami trzecimi, które często przewidują odmienne regulacje od zasad obowiązujących na jednolitym rynku. Na płaszczyźnie europejskiej uczestnicy dyskusji wskazali na kluczowe obszary europejskiej legislacji w zakresie prawnofinansowych instrumentów wspierania rolnictwa, instrumentów rolnośrodowiskowych oraz prawa żywnościowego. Jednocześnie zwrócili uwagę na rosnącą rolę ustawodawstwa UE wobec bezpośredniego obowiązywania norm rozporządzeń Rady WE i Komisji WE w państwach członkowskich, bez potrzeby ich inkorporowania i transponowania do krajowych porządków prawnych, ale też ich wpływ na ustawodawstwa krajów pozostających poza Unią, takich jak Szwajcaria, czy ubiegająca się o członkostwo Turcja. W polskim raporcie narodowym autorstwa prof. dr hab. R. Budzinowskiego, prof. dr hab. M. Korzyckiej-Iwanow i mgr. S. Balceraka zwrócono uwagę na wszystkie 
płaszczyzny rozwoju prawa rolnego. W szczególności podkreślono, że rozwój polskiego prawa rolnego $\mathrm{w}$ ostatnich latach jest ściśle związany z członkostwem w EU, co wpłynęło również na rozszerzenie zakresu tematycznego o nowe aspekty: rolnośrodowiskowe, socjalne, terytorialne czy bezpieczeństwa żywności. Jednocześnie wskazano na nadmierną szczegółowość, wręcz kazuistykę ustawodawstwa unijnego i jego częste zmiany, jako czynnik negatywnie wpływający na rozwój ustawodawstwa krajowego w zakresie prawa rolnego. Uwagi podsumowujące polskiego raportu były w tym zakresie zbieżne z projektem raportu końcowego. Zwrócono uwagę, że krajowe regulacje tworzą zespoły pojęć, definicji i konstrukcji nie do końca spójnych z pojęciami i konstrukcjami funkcjonującymi od dawna w krajowym porządku prawnym oraz w ustawodawstwie UE. Decydująca rola w zakresie wykładni przepisów prawa przypadnie zatem praktyce orzeczniczej organów administracji i sądów administracyjnych.

W ostatnim dniu Kongresu, na wspólnej sesji przedstawione zostały projekty raportów końcowych wszystkich komisji. Podsumowano również działalność CEDR w ostatnim okresie, zwracając szczególną uwagę na rolę organizacji w zakresie prawa rolnego i jej współdziałanie z Komisją Europejską. Ponadto uhonorowano osoby zasłużone dla rozwoju prawa rolnego, w szczególności Srebrny Medal CEDR otrzymał prof. dr hab. A. Lichorowicz. W trakcie obrad zamykających Kongres uczczono również pamięć zmarłego w tym roku prof. dr hab. A. Stelmachowskiego - zasłużonego dla rozwoju prawa rolnego, wieloletniego przewodniczącego Polskiego Stowarzyszenia Prawników Agrarystów, członka władz CEDR.

Uczestnicy Kongresu wysoko ocenili organizację Kongresu zarówno w sferze merytorycznej - doboru tematów, jak i w sferze organizacyjnej. Szczególnej oprawy obradom poszczególnych komisji nadawało miejsce organizacji Kongresu - Uniwersytet w Cambridge, który w tym roku obchodzi swoje 800-lecie. 